\title{
ARQUEOLOGIA HISTÓRICA E SERTANEJA NO SERIDÓ POTIGUAR \\ O Sítio Culumins, Caicó, Rio Grande do Norte, Brasil
}

\author{
HISTORICAL ARCHEOLOGY AND BACKGROUND \\ IN SERIDÓ POTIGUAR THE \\ Sítio Culumins, Caicó, Rio Grande do Norte, Brazil
}

\author{
Abrahão Sanderson Nunes Fernandes da Silva ${ }^{1}$ \\ abrahaosanderson@hotmail.com \\ Hozana Danize Lopes de Souza ${ }^{2}$ \\ hozanadanize.l@gmail.com \\ Kayann Gomes Batista ${ }^{1}$ \\ kay_gomes@ufrn.edu.br
}

\section{RESUMO}

As casas de fazenda, suas estruturas associadas e demais vestígios presentes nesses lugares, foram escolhidos como forma de desenvolver visões sobre as populações sertanejas que habitaram territórios do atual Seridó norte-riograndense, desde as últimas décadas do século XVIII até a primeira metade do século XX. A partir de pesquisas arqueológicas produziram-se dados sobre a tralha doméstica que relacionam o sítio arqueológico Culumins com outros sítios de populações sertanejas, mas ao mesmo tempo o diferencia entre esses devido ao contexto de casa sede de fazenda, abrindo espaço para hipóteses de trabalho sobre o sertão e os sertanejos no Seridó Potiguar.

Palavras-chave: Seridó; Casas de fazenda; Arqueologia; História; Sertão.

${ }^{1}$ Departamento de História - CERES/UFRN.

${ }^{2}$ Programa de Pós-Graduação em História - MHIST/CERES/UFRN. 


\begin{abstract}
Farmhouses and their spaces, their associated structures and other traces present, were chosen as a way to develop visions on the "sertanejos" that inhabited territories of the current Seridó "norte-riograndens", from the last decades of the $18^{\text {th }}$ century to the first half of the $20^{\text {th }}$ century. Based on archaeological research, the data on domestic waste at the Culumins archaeological site relate this space to other sites of "sertanejos", but also different them among them in view of their household context, opening space for working hypotheses about the "sertão" and the "sertanejos" in Seridó Potiguar.
\end{abstract}

Keywords: Seridó; Farmhouse; Archaeology; History; Sertão.

\title{
O PROJETO “ARQUEOLOGIA EM CASAS DE FAZENDA NA REGIÃO SERIDÓ: ESPACIALIDADES, TEMPORALIDADES E SOCIABILIDADES NO SERTÃO DO RIO GRANDE DO NORTE”
}

As evidências arqueológicas, transformadas em dados ou informação pelos arqueólogos, reportam-se a múltiplos contextos de ocupação humana em múltiplas temporalidades e espaços. "A Arqueologia evidencia facetas das sociedades, descobre peculiaridades de um passado às vezes esquecido e faz aflorar os indicadores da memória”. (BRUNO, 1995: 142).

O Seridó potiguar é uma área no centro-sul do Rio Grande do Norte que faz divisa ao sul com o estado da Paraíba. Área sertaneja de clima semiárido, com baixo regime hídrico e por consequência períodos de extrema seca. Sob o ponto de vista arqueológico, constitui-se em território fértil para a ocorrência de sítios e tem esse potencial destacado desde os anos 1980, a partir de uma série de trabalhos que 
identificou e oportunizou a análise de uma grande quantidade de dados, principalmente, no campo da arqueologia pré-histórica. (MARTIN, 2013).

Contudo, destaca-se que no Rio Grande do Norte de forma mais ampla e na região Seridó, em particular, a arqueologia histórica ${ }^{3}$ não têm ocupado espaço de produção específico e invariavelmente as fontes arqueológicas históricas são majoritariamente tratadas de forma complementar aos estudos históricos (SILVA, 2010). "Esta arqueologia não tem sido devidamente pensada como um campo de pesquisa definido por problemáticas e metodologias próprias e inserida dentro das discussões no âmbito da arqueologia e sua relação com as ciências sociais". (SILVA, 2010: 69).

Neste sentido, observamos naquilo que diz respeito às temporalidades ligadas ao período colonial e as espacialidades associadas aos diversos tipos de fazendas existentes à época, que ocorrem ainda visões superficiais (SILVA, 2006), motivadas, por exemplo, pela ausência de discussões/trabalhos que abordem questões como as relacionadas ao estabelecimento de modelos de "organização

\footnotetext{
3 “'Historical Archaeology' means different things to different people. For some, the field is the archaeology of European colonial expansion and subsequent post-Columbian peoples (Falk 1991; Leone 1995; Paynter 2000a). For others, it is the archaeology of capitalism (Leone and Potter 1988:19). For yet others, historical archaeology is the outcome of the rich play between word and object, text and artifact (e.g., Andrén 1998). Many believe that this latter aspect defines historical archaeology by its method rather than its content (Orser 1996a:23-24; see also Schuyler 1978) or by the uniqueness of the written word for inscribing history (Funari et al. 1999a:9-10)" (HALL \& SILLIMAN, 2006: 01).
} 
espacial nas propriedades rurais do tipo fazenda". (CARRÉRA \& SURYA, 2008: 2).

A implantação de fazendas no Seridó potiguar trouxe também a alocação de espaços de moradia e vivências. Inicialmente, ainda no século XVII, é provável que tenham existido moradias que não resistiram ao tempo, devido ao fato de terem sido construídas em taipa de mão com o "madeiramento amarrado com couro cru, térreas, chão de barro batido, de planta retangular e coberta em duas águas, com telhado de beira-e-bica". (DINIZ, 2008: 92).

Porém, a evolução para outras formas de alvenaria, embora lenta, ocorreu em todo o espaço seridoense havendo nos séculos posteriores (XVIII e XIX) a implantação de "edificações mais amplas, com cumeeiras mais altas, que favoreceu o aparecimento de sótãos, etc”. (MEDEIROS, 1983 apud DINIZ, 2008: 92). Este processo de evolução, no que cumpre as casas de fazenda no sertão do Seridó potiguar ocorre de maneira que, o "século XIX, foi marcado pela construção de grandes casas de fazenda, habitadas pela família do proprietário e seus agregados, assistentes e escravos negros". (DINIZ, 2008: 92).

Além da espacialidade ou prática do espaço, destacamos ainda, sob o ponto de vista econômico e das relações sociais, o papel autossuficiente de diversas dessas fazendas, 
“isto é, em cada uma delas era produzido o necessário à sobrevivência de seus moradores: os alimentos (feijão, farinha, milho, carne e peixe salgados, queijos, rapadura e aguardente de cana produzidos em pequenos engenhos - os 'bangüês'); os tecidos e redes feitos com algodão nativo em rocas, fusos e teares; a louça, tijolos e telhas de barro; as ferramentas e algumas armas; os inúmeros objetos de uso diário feitos de couro, etc. Nessa produção, o saber indígena transmitido aos colonos e as matérias-primas locais - como o barro e as fibras e óleos vegetais desempenharam um papel fundamental”. (MONTEIRO, 2002: 104 - Grifo nosso).

Esta situação nos remete a um cenário em que o comércio seria, no contexto do século XVIII e de grande parte do século XIX, pouco desenvolvido. Transações comerciais ocorreriam através da troca de produtos, como algodão e farinha. "As moedas, feitas primeiramente de cobre, eram raras, sobretudo no interior. Com o tempo, pequenos comerciantes ambulantes - os 'mascates' - passariam a percorrer o sertão, trazendo mercadorias importadas da Europa, pelo porto de Recife". (MONTEIRO, 2002: 105). Ainda assim, mesmo a geração de um fluxo a partir da comercialização dessas mercadorias, não altera a maioria dos contextos no sertão nordestino, particularmente, nas áreas dos atuais estados do Ceará, Paraíba e Rio Grande do Norte. Nesses espaços, podemos pensar na produção e circulação de bens locais 
"demonstrando uma situação de quase autossuficiência com relação aos produtos do mercado externo. Esta autonomia, marcada pela dependência dos produtos locais e, consequentemente, pela importância fundamental das esferas de interação local e regional, é característica de uma economia sub-capitalizada, e, portanto, de uma sociedade que deve ser entendida em seus próprios termos, antes do que através do uso de categorizações genéricas como status socioeconômico e ideologia de consumo". (SYMANSKI, 2008: 93 - Grifo do autor).

Assim, tomando por base os elementos destacados anteriormente, é que foi estruturado o projeto de pesquisa Arqueologia em casas de fazenda na região Seridó: espacialidades, temporalidades e sociabilidades no sertão do Rio Grande do Norte ${ }^{4}$. Estruturamos os eixos da proposta em relação ao contexto histórico das fazendas, nos aspectos que pretendem ser abordados pelo projeto: espacialidades, sociabilidades e temporalidades. Assim sendo, de forma global, a pesquisa busca compreender os espaços habitados e os possíveis padrões em relação aos modos de vida dos grupos nesses locais, os bens móveis e também os imóveis, como as estruturas de moradia ou de suporte, como fornos e cercas, por exemplo, e, estando essas evidências em situações de refugo "primário" ou "secundário". (ALLISON, 1998).

\footnotetext{
${ }^{4}$ Projeto cadastrado junto a Pró-Reitoria de Pesquisa da Universidade Federal do Rio Grande do Norte, com autorização de pesquisa publicada no Diário Oficial da União em 22 de outubro de 2018, com retificação também publicada no DOU, em 14 de janeiro de 2019.
} 
Outra importante perspectiva deste projeto, ocorre sob a ótica de uma arqueologia sertaneja e não apenas uma arqueologia desenvolvida no sertão. Isto é, entendemos que a "Arqueologia raras vezes olhou populações sertanejas no semiárido, mediante o destaque aos sítios monumentais (igrejas, fortes, engenhos) do litoral e, claro, dos contextos pré-coloniais". (SOUZA, 2015: 41-42).

Neste sentido, os pressupostos associados ao projeto nos fazem entender que, de forma semelhante às populações negras, indígenas e outros grupos deixados à margem do processo de escrita da história, as populações sertanejas também padecem com uma carência de discussões. De forma semelhante a "nova história indígena" (MONTEIRO, 2001), compreendemos que as histórias dos sertanejos também encontram na cultura material um amplo arcabouço para discussão e reflexão sobre suas vivências (HERBERTS, 2019), "permitindo penetrar no universo daqueles que não tiveram o direito e a possibilidade de escrever sua própria história”. (ZANETTINI, 2003: n.p). É assim, pois, que observamos as fazendas na região Seridó e as ligadas ao projeto em particular (Figura 01). 

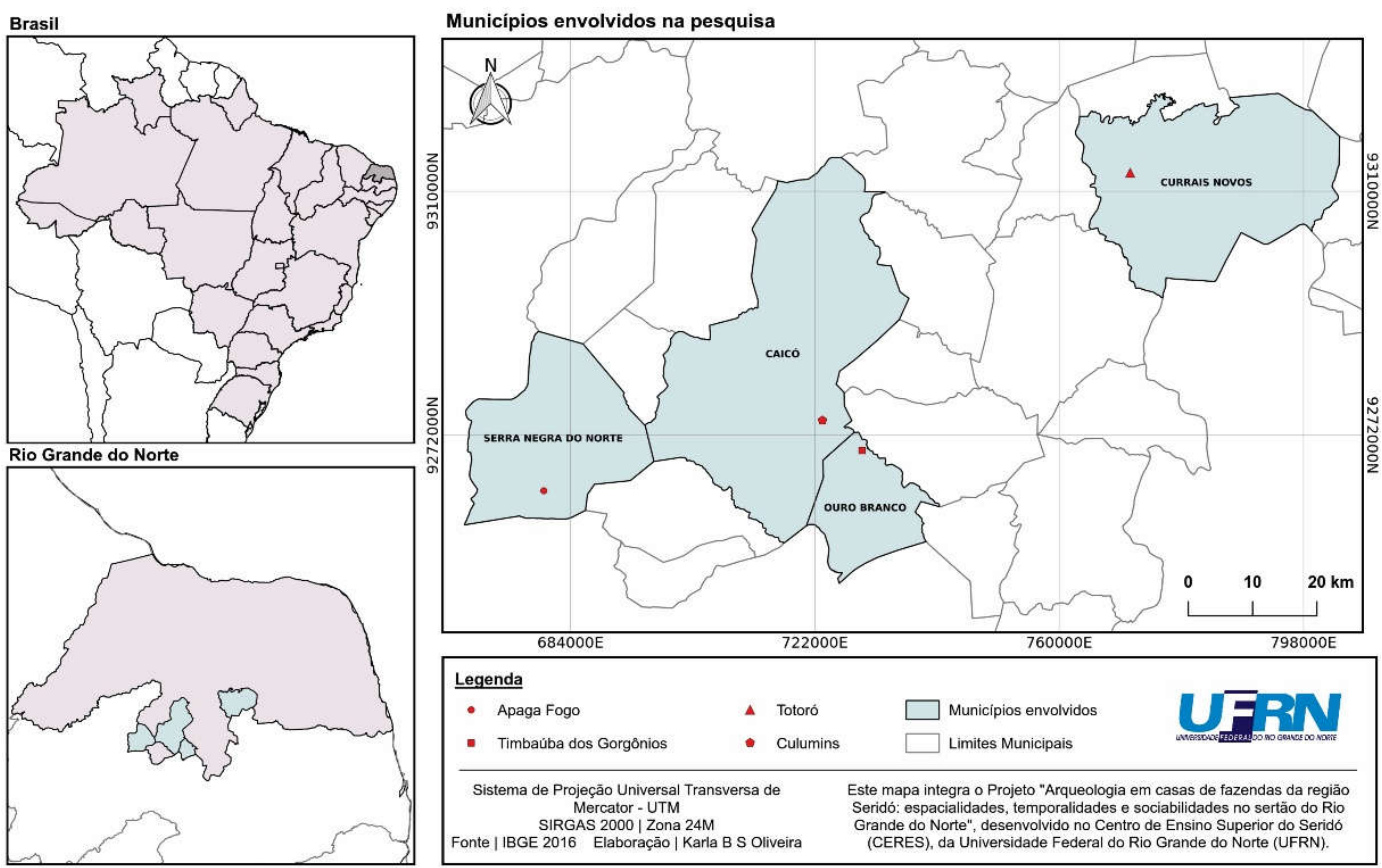

Figura 1. Mapa com a localização de fazendas que atuam como locais de pesquisa no projeto: Arqueologia em casas de fazenda na região Seridó: espacialidades, temporalidades e sociabilidades no sertão do Rio Grande do Norte.

Nesses lugares há na superfície: estruturas de alvenaria, concentrações de materiais arqueológicos e peças isoladas; fragmentos de vidro, ferro e diferentes tipos de louça, principalmente cerâmicas, todas evidências relacionadas às vivências das pessoas que utilizaram os espaços desde o período colonial e sobre as quais importanos saber (Figura 02). 


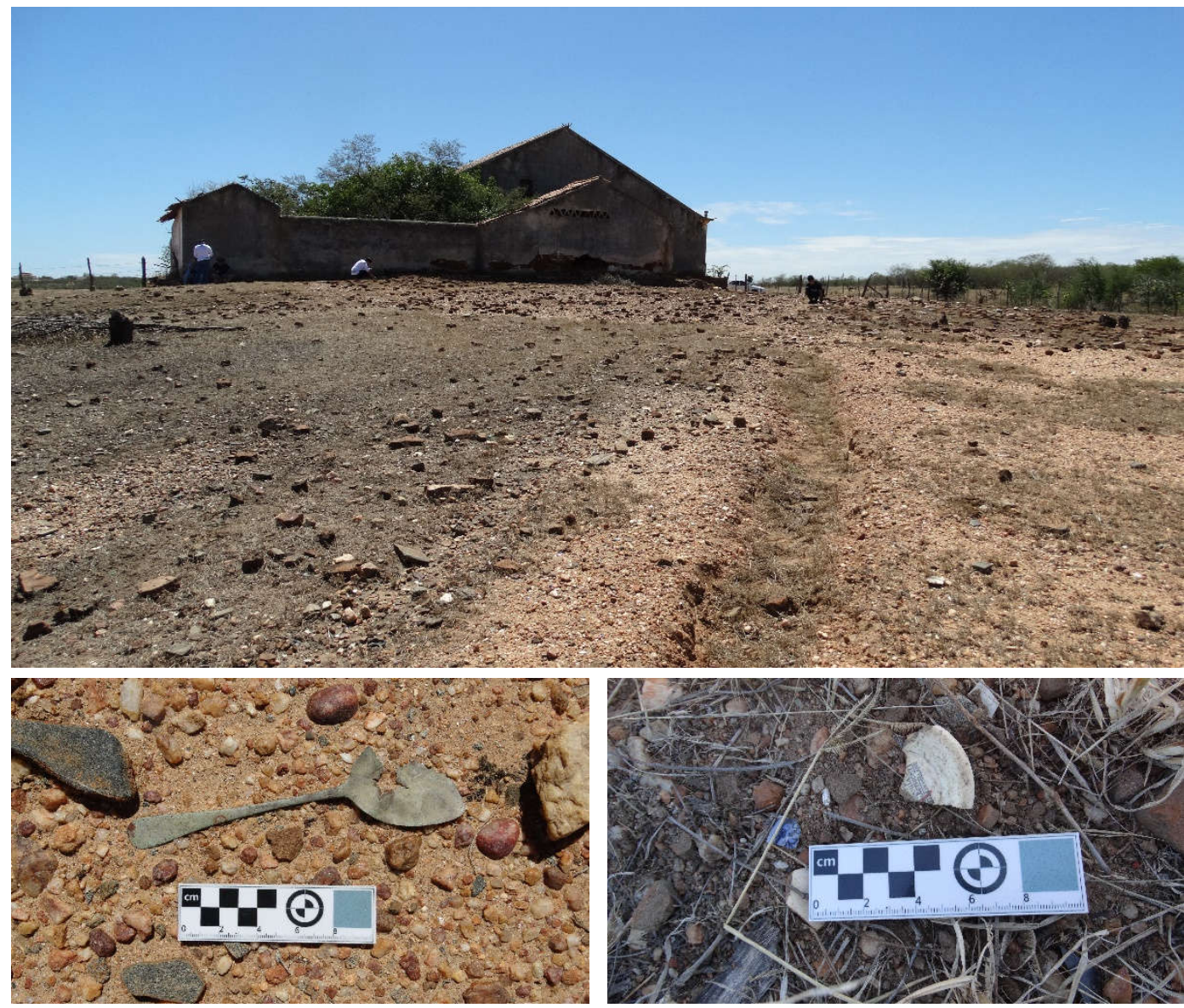

Figura 2. Composição de imagens, evidenciando a superfície na área externa da fazenda Timbaúba dos Gorgônios, em Ouro Branco/RN. Em detalhe, fragmentos de faianças e uma colher fragmentada. Fotografia e montagem: Abrahão Sanderson.

Planejado para ser executado em dois anos, o projeto de pesquisa "Arqueologia em casas de fazenda na região Seridó: espacialidades, temporalidades e sociabilidades no sertão do Rio Grande do Norte" teve os trabalhos de campo iniciados com a realização da primeira campanha de escavação no sítio arqueológico Culumins, 
localizado em território do município de Caicó/RN. Esta primeira campanha gerou a maioria do acervo de pesquisa relacionado a este sítio arqueológico 5 e, por isso, o Culumins foi escolhido como estudo de caso no presente texto, que abordará ainda, além das discussões inerentes aos dados arqueológicos, outros elementos de discussão associados às concepções de estudo no âmbito desse projeto, tais como, as discussões sobre cultura material, território, casas de fazenda, dinâmicas sociais e, inicialmente, sertão e arqueologia.

\section{SOBRE O SERTÃO E A ARQUEOLOGIA SERTANEJA}

Compreendemos, em meio as diferentes noções de "sertão" (AMADO, 1995; NEVES, 2003), que o sertão do Seridó é um espaço e região constituída historicamente e a qual é, parafraseando Diniz (2013), “um sertão entre tantos outros" egresso de formações variadas e dotado de suas respectivas peculiaridades.

O sertão se refere a ambientes polissêmicos e dicotômicos, agregando referências geográficas, sociais, econômicas e culturais e, se tornando portador de uma série de significados simbólicos, com uma carga que atua na valoração deste espaço através

\footnotetext{
${ }^{5}$ Foram realizadas duas campanhas de escavação no sítio arqueológico Culumins, que totalizaram uma área escavada de 26 metros quadrados. Os dados referentes a segunda campanha de escavação, realizada entre os meses de novembro e dezembro de 2019 serão abordados junto com outros dados, não constantes no presente texto, na dissertação de mestrado em desenvolvimento pela pesquisadora Hozana Danize Lopes de Souza junto ao Programa de Pós-Graduação em História - Mestrado em História dos Sertões - CERES/UFRN, sob a orientação do professor Dr. Abrahão Sanderson Nunes Fernandes da Silva.
} 
da alternância entre olhares de cunho ora positivo, ora negativo e evidenciando o fato de que o "sertão" é uma designação com existência própria, daí ser possivelmente entendido também como um substantivo concreto.

Neste sentido, destacamos que o sertão, principalmente aquele ligado ao semiárido nordestino, é desde o período colonial um território frequentemente estereotipado; é um lugar e não necessariamente um ambiente biológico e fisicamente delimitado, sendo que muitas vezes é até definido pela ausências de vidas humanas, pois, "a invisibilidade da presença humana é muitas vezes levantada como um traço característico desses espaços, não raro definidos como 'vazios demográficos' ou 'terras desocupadas'”. (MACHADO, 1995 apud MORAES, 2003: 1).

Para a autora Chimamanda Ngozi Adichie, o controle e os discursos que se estabelecem padronizantes ao contar uma história trazem o perigo da formação de uma "História Única". Segundo Adichie, “o poder é a habilidade não apenas de contar a história de outra pessoa, mas de fazer com que ela seja sua história definitiva". (ADICHIE, 2009. p. 23). Lembremo-nos, pois, neste caso, dos diversos viajantes, naturalistas e repórteres que passaram pelo semiárido nordestino e o documentaram, na maioria das vezes reproduzindo nos textos seus valores e julgamentos, reflexos de alteridades que privilegiaram a si na relação com, ou sobre, o outro. (BONATO, 2010). 
Seguindo este pensamento, as noções sobre o sertão passaram por um processo que aqui chamaremos de "substantivação". Ou seja, a partir de construções histórico/culturais e também geográficas, o termo "sertão" passou a apresentar aspectos (geo)espaciais e culturais padronizados e estáticos. Como se o sertão fosse um único, como se fosse seca, fome e pobreza. O sertão isolado, rústico e muitas vezes bárbaro, não importando pressupostos fundamentais para compreensão de desenvolvimentos sócio-históricos particulares, como espacialidades e temporalidades.

Diante disto, percebemos ainda, assim como outros autores o fizeram e fazem, que "Quando se dirigem ao Sertão, as ciências sociais em geral e a historiografia em particular o tem tratado numa visão de modernização pelo reverso. Eles costumam focalizar o misticismo, messianismo, o milenarismo e/ou o demonismo/a demonização do homem e da natureza. Elas vêem nestes fenômenos o lado mais destacado da normalidade sertaneja, considerada paradigmaticamente pré-moderna. Tratando das supostas utopias sertanejas, constituem o Sertão como topos, como lugar da Pré- ou da Anti-Modernidade". (BARTELT, 1999: 42).

\footnotetext{
${ }^{6}$ Através do processo de substantivação, o sertão é concreto a medida que os indivíduos possuem uma visão pré-concebida deste, reduzindo-o somente às características padronizantes e frequentemente observáveis fisicamente, como, por exemplo, a seca. No entanto, o sertão também pode ser abstrato, no sentido de que cada sertão tem suas particularidades ideativas; é o sertão das vivências, dos sentimentos e das mesclas, é o sertão que se desdobra em vários sertões particulares e que não podem ser visualizados estando preso aos padrões comumente impostos, por envolverem relações diretas de "pertencimento" e "identidade" (POLLAK, 1992).
} 
Essa inobservância sobre as características particulares das populações sertanejas do Nordeste brasileiro, aliado a essa escolha do "sertão" como algo construído com argumentos que reforçam sua "não modernidade", possivelmente, inibiu a ocorrência de discussões que aprofundassem análises mais específicas sobre as localidades do semiárido nordestino naquilo que cumpre, por exemplo, interesses de poder, violência e, particularmente no caso deste texto, a cultura material.

Tendo em vista constatações semelhantes às que nos referimos há, na arqueologia histórica praticada desde a década de 1990 no Brasil, trabalhos que pontuam a necessidade de uma prática arqueológica que reforce um discurso o qual venha a abordar as populações sertanejas do semiárido nordestino, dentro de suas especificidades, suas relações simbólicas específicas, respectivas valorações do espaço, capacidade criativa e inventiva, sua economia e relações sociais (ZANETTINI, 1996; ZANETTINI, 2003; SYMANSKI, 2008; AMARAL, 2012; REGO, 2013; SOUZA, 2015; QUEIROZ, 2015; SOUZA, 2017; HERBERTS, 2019; AMARAL, 2019).

Isto posto, observamos ainda que, de forma geral, é possível afirmar que a partir dos anos 1990 a arqueologia histórica no Brasil muda de fase, saindo de uma "Arqueologia de Restauração" (LIMA, 1993: 229), em favor de "uma vertente crítica cada vez mais popular, focalizada, sobretudo, na dimensão política da subdisciplina, considerando seu potencial no empoderamento dos grupos 
oprimidos, tidos como marginalizados pela historiografia" (SYMANSKI, 2009: 298).

Neste sentido, em meados dos anos 1990 é que encontramos nos trabalhos de Zanettini (ZANETTINI, 1996, 2003), o que elencamos como preocupações iniciais com as populações sertanejas do semiárido nordestino. Trata-se, neste caso, dos trabalhos arqueológicos realizados tendo em vista a implantação do Parque Estadual de Canudos, no município de Canudos/BA, um espaço cuja principal "contribuição para a realidade sertaneja seria o estudo interdisciplinar das comunidades do Sertão de Canudos”. (SÁ, 1997: 40).

"A Arqueologia nos impelia, no caso de Canudos, rumo ao contato direto com os seguidores de Antonio Conselheiro, de uma forma muito interessante, permitindo penetrar no universo daqueles que não tiveram o direito e a possibilidade de escrever sua própria história". (ZANETTINI, 2003: n/p).

Os dados arqueológicos levantados suscitaram diversas discussões e questionamentos, cujas respostas poderiam estar relacionadas não somente a arqueologia, mas em favor de uma interdisciplinaridade que envolvesse antropologia, história, geografia, sociologia e outras ciências que manifestassem preocupações com abordagens concretas da natureza humana de um "sertão iletrado". (ZANETTINI, 1996). Encaixa-se neste pensamento, por exemplo, os elementos ligados a uma região semiárida povoada na longa duração (BRAUDEL, 
2014), isto, conforme os dados relacionados às populações pré-coloniais que ocuparam as margens do rio Vaza Barris (ZANETTINI, 1996; 2003).

Para além dos objetivos de compreensão dos conflitos bélicos existentes e ligados a implantação da Canudos Conselheirista, há discussões que vão em sentido contrário ao que foi solidificado por diversas produções e, principalmente, por elementos expostos inicialmente na obra de Euclides da Cunha, Os Sertões, "essa obra literária por sua densidade, intensidade e qualidade acabou ganhando o foro de fonte histórica, tornando-se para muitos a verdade histórica". (ZANETTINI, 2003: $\mathrm{n} / \mathrm{p})$.

Neste sentido, Zanettini (1996; 2003) evidencia preocupações com uma Canudos estereotipada e que, sob o ponto de vista arqueológico não foi implantada em uma fazenda desocupada; cuja pretensa igualdade entre os grupos precisa ser melhor compreendida ou estudada, face a identificação de outras casas de fazenda na área que indicam a existência grupos domésticos de hábitos distintos dos de grande parte da população que secundava o Conselheiro.

O sentimento de pertença ao lugar, é outro ponto destacado em uma região cujas terras foram inicialmente pertencentes à família Garcia d'Ávila e cuja permanência das pessoas no lugar, mesmo após a guerra narrada por Euclides da Cunha, foi delimitada através da implantação pelos sobreviventes de uma nova Canudos; nas margens do rio Umburanas; até mesmo os conflitos bélicos, careceriam de serem 
vistos sob o "jeito canudense de guerrear" e as dificuldades que isso trouxe às tropas do Estado, além da percepção de diferentes grupos que se envolveram no conflito entre os canudenses ou mesmo em meio às tropas do Estado e que envolve, também, a compreensão de questões ligadas a diversos contextos, como, por exemplo, aqueles ligados diáspora de populações africanas.

Mas para além dos elementos já ressaltados, os trabalhos de Zanettini abordam ainda a mitificação das proporções dos templos religiosos e a imagética construída em torno deles, mas também ressalta os aspectos de uma Canudos organizada, com pessoas que "buscavam dar sentido e forma as suas ações". (ZANETTINI, 2003: $\mathrm{n} / \mathrm{p})$.

Ainda na primeira década dos anos 2000, vemos no trabalho de Symanski (2008) o que podemos caracterizar como o primeiro enfoque localizado em unidades domésticas específicas, localizadas no sertão do Ceará, entendidas pelo autor como ligadas a populações camponesas, e as quais até então não haviam sido abordadas nos textos de arqueologia histórica ligados às populações sertanejas do semiárido nordestino. Sob os pontos de vista de variabilidades e variações, a cultura material (ou materialidade) sertaneja, nos casos analisados pelo autor indicaram uma maior relação com produtos locais e regionais.

Embora identifique produtos comercializados de forma mais global, os objetos analisados teriam maior valor pelo que são e não teriam seu uso ou custo 
diferenciado por ser de um lugar ou de outro, implicando na estruturação de relações econômicas e sociais específicas (SYMANSKI, 2008). Essas relações ocorreriam, desde o século XVII em "dois sertões", o das grandes propriedades e de seus agregados no entorno e, o sertão das pequenas propriedades arrendadas ou de trabalhadores livres, sendo que nesses dois sertões haveria como elemento norteador das materialidades o fato de que os grupos domésticos não seriam formados exclusivamente por famílias de parentesco consanguíneo e sim por pessoas que compartilham espaços e decisões.

A partir disso, haveria a formação de grupos de objetos, nos quais estariam contidos categorias de artefatos específicos e de função/simbologia diferenciada. Assim, teriam-se as peças associadas ao maior "valor de uso", que visavam a satisfação de necessidades primárias como, por exemplo, comer e beber; as peças associadas a um maior potencial fiduciário, entendido como "valor de troca" e embora não seja descartado também o valor de uso dessas, seu maior potencial estaria, pois, no emprego para transações comerciais; o "valor simbólico" poderia ser aplicado a qualquer peça das categorias de "valor" anterior, contudo, se diferencia pelo seu caráter contextual e que não necessariamente representa a consciência sobre as desigualdades (SYMANSKI, 2008). Assim sendo, por exemplo, faianças finas teriam maior valor de troca e as cerâmicas utilitárias um maior valor de uso.

São justamente os objetos cerâmicos, desde que não empregados em construções de casas, daí serem utilitários, os que poderiam expressar as maiores esferas de 
interação comercial nos níveis locais e regional, implicando assim em uma maior autonomia em relação aos mercados nacional e internacional, com itens do cotidiano em um sistema de trocas local, centrado nas feiras (SYMANSKI, 2008). Tal contexto, evidencia ainda Symanski (2008), reportar-se-ia ainda no século XIX a uma economia sub-capitalizada sustentada por lógicas intrínsecas, diferenciandose de sociedades capitalistas de lógicas extrínsecas. O trabalho de Symanski (2008) já pontuava a cerâmica como uma categoria material bastante expressiva no registro arqueológico associado a populações sertanejas, talvez por isso, trabalhos posteriores abordaram esses objetos a partir de análises mais específicas que alinharam referentes arqueológicos, com referenciais etnoarqueológicos.

O trabalho de Amaral (2012) associa a etnoarqueologia e a arqueologia histórica no estudo dos sítios arqueológicos Tacaimbó 1 e Tacaimbó 2, como forma de analisar a produção oleira da região Agreste Central de Pernambuco. Isso se desenvolveu a partir da percepção que as cerâmicas coletadas nos sítios possuíam semelhanças com as cerâmicas utilitárias produzidas nessa região e que eram comercializadas nas feiras-livres. No decorrer do trabalho, a autora utiliza para se referir a produção regional as categorias êmicas, assim, a cerâmica é chamada de loiça de barro e as artesãs de loiceiras, por se tratar de um ofício predominantemente feminino. A concepção da etnoarqueologia foi empregada devido a possibilidade de continuidade histórica entre a loiça de barro arqueológica presente nos sítios, com aquelas ainda produzidas pelas loiceiras. 
Foi desenvolvido o registro das cadeias operatórias de sete comunidades pernambucanas, com ênfase nos processos tecnológicos empreendidos, ferramentas utilizadas, o tempo e quantidade de pessoas envolvidas. Com isso, houve a construção de uma matriz de correlatos com a análise da cerâmica arqueológica, entre alguns pontos podemos destacar a presença e ausência de elementos minerais na pasta como forma de tornar a vasilha mais resistente, a adição de antiplásticos. Outro correlato apontado é sobre a técnica de manufatura determinada pela modelagem, onde é adicionada pseudorroletes à técnica de alisamento da peça para obter a impermeabilidade nas superfícies na etapa de acabamento, e o uso do polimento e engobo em vasilhas de armazenamento de líquidos. Esses correlatos relacionam um comportamento de técnica e matéria entre ambas as loiças que, segundo a autora, podem auxiliar na caracterização dos vestígios das cerâmicas arqueológicas dessa região de Pernambuco (AMARAL, 2012).

A importância dessa abordagem envolvendo a etnoarqueologia e acompanhando de forma direta a produção e o conhecimento das loiceiras favorece a desconstrução dos discursos caracterizados como elitista, excludente e dominante, possibilitando a inclusão e legitimação do ponto de vista dessas populações sobre seu próprio passado. Nesse sentido, outro objetivo traçado no trabalho foi contribuir para a reconstrução de uma história local onde esses grupos sertanejos sejam agentes e tenham voz. Portanto, esse trabalho faz parte de perspectivas descolonizadas, multivocais e inclusivas acerca das populações sertanejas que foram deixadas a margem de registros documentais variados (AMARAL, 2012). 
Também relacionado ao estado de Pernambuco, tem-se o trabalho de Herbert Moura Rego, “As panelas de barro de Pernambuco - Do Século XIX e XX” (2013). O mesmo apresenta muita importância para o estudo das sociedades sertanejas do Nordeste, principalmente, pelo estudo etnoarqueológico desenvolvido na análise das panelas de barro, tão presentes e atuantes nessas populações.

As análises transcorreram tendo em vista a compreensão das peças sob o ponto de vista da sequência de operações, contexto que não se vincularia somente aos aspectos da manufatura de produção. Nesse sentido, o autor manteve seu olhar, principalmente, para dois campos: o espaço, este que estaria ligado às cozinhas onde esses artefatos eram utilizados; e a posição ligada à estrutura simbólica voltada para a memória gustativa. (REGO, 2013).

É interessante lembramos, que na construção de seu pensamento, o autor não utiliza somente vestígios materiais. Mas recorre a inúmeras outras fontes, como imagens etnográficas, relatos de viajantes (que passaram por Pernambuco no século XIX), nas entrevistas orais dos próprios loiceiro(a)s contemporâneos a produção do trabalho, como também, fotografias do início do século XX. Nesse sentido, a obra especifica que tanto os poucos relatos históricos, como as análises realizadas nos artefatos, apontam para uma padronização principalmente no modo de feitura desses objetos, o qual, apresenta o modelado como modo de confecção (REGO, 2013). 
Nessa perspectiva, o texto é importante pela sua contribuição a não pensar somente preso a um olhar, mas busca contextualizar os dados arqueológicos com outras fontes. Não obstante temos a ação análoga interpretativa entre as características físicas das panelas contemporâneas produzidas, com as verificadas do passado. Ademais, há também o fato de que "os trabalhos de análise destes tipos materiais que estão associados a grupos subalternos, puderam atingir os agentes sociais antes excluídos dos discursos”. (REGO, 2013: 30).

Indicando desde o título que se trata de uma abordagem mais ampla de populações sertanejas, sob a ótica da arqueologia, há o texto desenvolvido por Souza (2015), com foco de análise em regiões sertanejas de Pernambuco, Ceará e Piauí. Consiste na abordagem desses espaços para além dos discursos e representações que tratam o sertão pelas noções de estático, isolado, degradado e pobre. Seguindo esse pressuposto, sua perspectiva se estrutura pela análise da materialidade dessas populações, tendo como eixo as práticas de consumo.

Assim, a problematização se estabeleceu em perceber como essas práticas de consumo foram ressignificadas, considerando a relação fluida entre o âmbito local com o global no século XX. Por abarcar essa temporalidade, esse estudo foi desenvolvido no campo da Arqueologia do Passado Contemporâneo, que trata de períodos recentes onde usa-se a materialidade com o objetivo de tecer críticas a modernidade e a história dos séculos XX e XXI. Ainda que corresponda a um 
período bem documentado, a questão é que esse entendimento visa, com métodos e técnicas arqueológicas, recuperar aspectos de grupos que foram marginalizados, no sentido de que não geraram uma documentação escrita própria (SOUZA, 2015).

O consumo de objetos, as redes de produção, circulação, aquisição, uso, reutilização e descarte que ocorrem em níveis locais não podem ser separadas de contextos mais amplos. Isso é visível nas unidades domésticas da região nordestina, sobretudo, na área de descarte analisada por Souza (2015), essa área não possuía limites precisos e se localizava, geralmente, ao fundo da casa, estando distante dos espaços de sociabilidades. Nela se encontrava alguns objetos que foram utilizados, reutilizados e abandonados durante o período de ocupação; essa prática de descarte nesse tipo de ambiente permaneceu até o século XX. Acerca dos bens de consumo, quando comparado com o século XIX, o autor aponta que tiveram modificações.

Em primeiro lugar, em relação aos objetos cerâmicos utilizados no espaço doméstico, foram determinados como de produção local/regional, sofrendo alterações devido a chegada de novos bens e novas lógicas de consumo. Desses objetos, permaneceram aqueles recipientes destinados a cocção e armazenamento de água, havendo, portanto, o aumento do uso de objetos industrializados como vidros, plásticos, metais e louças. Outro elemento material importante nessa discussão, pois, relaciona o objeto material industrializado com a prática de reuso, corresponde as sandálias de borrachas que são indicadores que o consumo não representa o fim da vida do objeto. Isso foi percebido pelas rodinhas, feitas com a 
parte central do solado da sandália, confere, por conseguinte, o novo uso desse material seja como o aspecto lúdico, como rodas de carrinhos, ou alisadores de cerâmicas quando estão sendo produzidas (SOUZA, 2015).

Esse cenário não atribui que esses grupos foram submetidos ou aceitaram padrões e sistemas impostos, mas diz respeito a novas formas de vida marcada pela dinâmica de consumo que varia entre mudança e permanência. Souza (2015), defende que são por esses aspectos que a cultura material sertaneja não pode ser percebida como homogênea em relação aos comportamentos de consumo e hábitos culturais pautados como efeitos de uma industrialização e produção em massa. Desta forma, a ideia de sertão quando analisado pela materialidade permite perceber que as diferentes ações de abastecimento, circulação e usos da cultura material no século XX que estão atreladas com perspectivas de mudanças e permanências de práticas de consumo, relacionando uma produção local de cerâmica e o reuso atribuído as sandálias de borrachas de uma indústria.

Também em 2015, temos a defesa do trabalho de Luiz Antonio Pacheco de Queiroz, intitulado "Água fria é no pote do Cariri Cearense" (QUEIROZ, 2015). Neste trabalho enxergamos também o fruto da relação entre etnoarqueologia e arqueologia histórica, buscando-se a compreensão das mudanças culturais relacionadas ao uso dos potes cerâmicos, em face do avanço da economia mundial sobre modos de saber e fazer tradicionais, no semiárido nordestino e mais 
especificamente em municípios da região Cariri no estado do Ceará (QUEIROZ, 2015).

A produção ceramista nessa área foi identificada como tendo por objetivo principal “obter produtos úteis para armazenar e esfriar água" (QUEIROZ, 2015: 15). Para efeito de caracterização de sua área de pesquisa, Queiroz (2015) foge a generalizações amplas, estereotipadas, destacando o fato de que "lançar mãos de certas composições do Nordeste levaria a manifestar atitudes discriminatórias, distantes da realidade". (QUEIROZ, 2015: 19). Assim, neste trabalho o autor entende o sertão do Cariri Cearense a partir de suas especificidades locais e, consequentemente, alberga a cultura material por ele analisada dentro dessas óticas de relações com os meios de produção e, o papel do Estado e da ideologia católica na economia e saberes locais.

Para além da produção de dados arqueológicos ou etnoarqueológicos, o trabalho tem grande parte dos seus argumentos sustentados por documentação oral, "Esse caminho permitiu aproveitar a oportunidade de evidenciar as singularidades do agenciamento através das opiniões emitidas por aqueles que experimentaram situações relativas aos recipientes em estudo". (QUEIROZ, 2015: 45). Importante destacar que, a relação adaptativa das populações que lidam com a produção ceramista na região, dialogando com o ambiente e as perspectivas de seca, bem como com a diminuição na venda das vasilhas e desenvolvimento nessa época de 
"outras atividades, tais como a criação de alguns animais, comum entre loiceras e seus familiares". (QUEIROZ, 2015: 110 - Grifo do autor).

Identificando diferenças no saber e fazer das loiceras do Cariri, em termos de sua localização no Cariri pernambucano ou do lado cearense, Queiroz (2015) ainda pontua o impacto da economia mundial, com seus polímeros e metais, sobre a produção ceramistas na sua área de pesquisa. Destacando, contudo, que essa influência deve-se a adoção desses elementos no processo produtivo como forma de tornar a confecção de vasilhames mais eficiente e que isso não afeta a agência dessas loiceras, vez que os elementos identitários ainda se fazem presentes, "diante da continuidade da produção e uso posso afirmar com veemência que persiste junto à grande soma de materiais novos despejados pelo mercado globalizante no Cariri os potes arranhados e seus significados pujantes". (QUEIROZ, 2015: 151).

Aprofundando as discussões apresentadas no texto de 2015, Souza (2017) traz em sua tese de doutorado uma proposta estruturada em três eixos: consumo, mobilidade e paisagem. $\mathrm{O}$ foco mantém-se no sertão e nos camponeses do sertão, sendo o semiárido nordestino compreendido a partir de um olhar crítico, contrapondo-o às visões de estaticidade, pobreza e isolamento destinados, em muitos estudos, como elementos caracterizadores do sertão e dos sertanejos. Seu trabalho se desenvolve por uma análise macro, através da paisagem relacionadas as unidades domésticas e, por último, a área de descarte com o foco e problemáticas relacionadas ao consumo, mobilidade e os lugares da caatinga. 
O consumo é entendido através dos objetos domésticos localizados nas áreas de descarte, os quais são remetidos a uma produção local e a produção industrial. A mobilidade é observada por uma ótica que evidencia a produção do território e do lugar dos sertanejos, tendo em vista a como se desenvolveram as formas de obtenção de objetos e a construção do espaço doméstico, além dos caminhos, estradas e outras formas de circulação dessas pessoas. Já a paisagem, como elemento da cultura material, está inserida na estruturação da unidade doméstica, quer quando os recursos do meio eram empregados nas construções ou em relação a localização da casa e a proximidade com os cursos d'água, ou outros corpos hídricos (SOUZA, 2017).

A área doméstica abrange a casa, o terreiro e os espaços do entorno, através disso, Souza (2017) atribui a relação que os grupos estabeleceram com o ambiente da caatinga, atuando assim na criação, exploração e transformação da paisagem. Isso é visto por uma concepção de ordenação do espaço e do cotidiano por meio do consumo local, apresentado pelos objetos descartados no terreiro. Logo, "construção do local de moradia, da unidade doméstica, tem a ver com as relações espaciais, temporais, ecológicas e cognitivas com o ambiente, parcialmente construído por interações humanas, pautadas por questões de acesso diferenciado a recursos e ao poder sobre eles [...]". (SOUZA, 2017: 79). O sertão pela materialidade não é, consequentemente, estático ou vazio, mas é aquele onde possui 
coisas, pessoas e significados que difere de um discurso homogeneizado (SOUZA, 2017).

Também retomando um estudo anterior, a tese de Amaral (2019), retoma a aproximação com as loiceras pernambucanas por meio de uma investigação que buscou compreender as causas da permanência dos potes, jarras e quartinhas no cotidiano doméstico das loiceiras, em comparação com o uso de panelas que tiveram sua adoção reduzidas. Assim, é concentrado um olhar que permitiu uma reflexão voltada para os significados das mudanças e permanências na produção e no uso da loiça de barro nas comunidades de Belo Jardim, Altinho e Bezerros.

O termo sertões é utilizado de maneira ampla, como forma de designar a região estudada, caracterizada como áreas rurais de clima semiárido. Enquanto as loiceiras são detentoras do conhecimento tradicional desse tipo de manufatura, e os potes atuam como representações dessa população conhecida como sertaneja. É evidenciado que esse grupo esteve marginalizado no processo de construção dos conceitos de sertão e sertanejo, como também em estudos que buscassem ter esses indivíduos como foco de investigação (AMARAL, 2019).

A diminuição das panelas na produção das loiceiras têm como principal fator a substituição delas pelas panelas de alumínio e pela presença do fogão a gás, tratando-se assim de alterações nos modos de vida domésticos, ocasionadas pela inserção de produtos industrializados. Além do que, houve a desvalorização da 
loiça de barro, notada tanto no baixo custo de cada peça, quanto no interesse de pessoas mais jovens em continuar sua produção (AMARAL, 2019).

Todavia, a permanência de potes e jarras é defendido como uma forma de resistência e de preservação de um modo de vida que se encontra em vias de extinção, considerando que a introdução de produtos industrializados estivesse descaracterizando os traços locais. Ademais, a relação desses indivíduos com os recursos hídricos contribuiu para essa permanência, já que essa loiça é utilizada para o armazenamento e consumo da água, inclusive, desse modo, tendo análise semelhante à desenvolvida por Queiroz (2015).

A abordagem de Amaral (2019), possibilitou compreender o modo de vida sertanejo em uma reflexão que trata sobre seu passado e presente e as transformações culturais sofridas. Esses potes consistem como significativos para esse cotidiano doméstico, indicando lembranças da seca, escassez de água, bem como representam memórias dos períodos de chuva e abundância. Como modos de saber e fazer que se encaminham para o desaparecimento, pontua-se uma atenção para a necessidade de serem desenvolvidas ações que busquem a valorização e preservação desse tipo de conhecimento e produção.

Fechando essa revisão de literatura, há o trabalho de Ana Lucia Herberts sobre "Arqueologia das populações sertanejas do Nordeste brasileiro", apresentado em 2019. Em seu texto, Herberts (2019) destaca o distanciamento das pesquisas 
arqueológicas em relação às populações sertanejas e, tomando como base alguns dos autores abordados nesse texto (SOUZA, 2017; SYMANSKI, 2008) e relatórios de pesquisa ligados ao licenciamento ambiental de ferrovias e linhas de transmissão, discute os sítios identificados e apresentados no seu texto (HERBERTS, 2019).

Os sítios apresentados encontram-se em regiões semiáridas nos estados do Piauí e Ceará, possuindo uma cronologia associada, principalmente, ao século XX. São caracterizados de forma semelhante aos descritos por Souza $(2015 ; 2017)$,

"esses locais apresentaram uma diversidade de cultura material, abrangendo estruturas habitacionais remanescentes de casas de barro e vestígios de material construtivo, com o predomínio de fragmentos de cerâmica utilitária de produção local e regional, além de artefatos vítreos, metálicos, de louças e ósseos; compondo a tralha doméstica e alguns implementos de trabalho". (HERBERTS, 2019: n/p).

As cerâmicas de produção local são analisadas e comportam características também apresentadas em estudos anteriores, referidos neste artigo (AMARAL, 2012; REGO, 2013; QUEIROZ, 2015; SOUZA, 2017). A autora dedicou ainda atenção aos aspectos arquitetônicos das moradias, evidenciando alterações de padrões em face de um avanço de técnicas de alvenaria sobre a arquitetura vernacular, ainda encontrada em grande quantidade no semiárido nordestino. O trabalho de Herberts (2019), corrobora em diversos aspectos com os quadros caracterizados 
anteriormente neste texto e, tal qual os demais títulos apresentados nesta revisão, formaram eixos de estudo sobre as populações sertanejas que poderiam ou não se ver representados numa prática arqueológica sobre as populações sertanejas no Seridó potiguar.

\section{O SÍTIO CULUMINS, CAICÓ/RN: IDENTIFICAÇÃO E CARACTERIZAÇÃO ARQUEOLÓGICA}

Localizado no atual munícipio de Caicó/RN, o sítio Culumins está inserido no contexto que corresponde ao processo de interiorização da capitania do Rio Grande. Efetivada já no século XVII com a expansão da pecuária, as ocupações nas ribeiras do rio Seridó ocorreram, principalmente, com o estabelecimento das fazendas de criação de gado, que foram importantes para a conformação territorial da região Seridó.

O sítio Culumins corresponde a uma divisão de terras, que se encontra originalmente relacionada com as fazendas Umari e Manhoso, propriedades hoje localizadas no município de Ouro Branco/RN, vizinho a Caicó/RN. Essas propriedades ainda permanecem em posse dos descendentes de Cosme Pereira da Costa, nascido em 1768 na freguesia de Mamanguape, na Paraíba e que teria adquirido a fazenda Umari, que já existia desde 1788, através de permuta em 1821, tendo pertencido a Domingo Alves dos Santos, descendente de família portuguesa e primeiro proprietário das terras (MEDEIROS FILHO, 1983). 
Em meio às habitações no Seridó já desde o período colonial, a casa sede ocupava um lugar central na estrutura da fazenda. As chamadas de casas de morada comumentemente eram construídas com materiais disponíveis na região. No que se refere aos modelos construtivos, se sobressai aquelas de taipa, que marcam um período inicial de ocupação, elas eram construídas a partir do barro amassado, madeiras e cobertas com telhas.

Esses materiais empregados nesse tipo de construção, não apresentavam resistência e durabilidade, portanto, atualmente são escassas suas evidências sob o ponto de vista arqueológico, considerando ainda que era comum a reutilização do material, sendo aplicado em novas construções. A transição desse modelo se determina pela adoção dos tijolos, que possibilitaram a estruturação de edificações mais amplas, onde esse tipo de alvenaria, vigente no século XIX, se encontra, em grande parte, preservadas integrando a paisagem rural da região, ainda que tenha sofrido algumas modificações em sua arquitetura. Dessa forma, são esses dois tipos construtivos de moradia que se destacam quando se trata do processo de estabelecimento das habitações ligadas a fazendas ou sítios ${ }^{7}$ no Seridó (MEDEIROS FILHO, 1983; FEIJÓ, 2002; MACÊDO, 2007; DINIZ, 2008; BORGES, 2015).

\footnotetext{
${ }^{7}$ No que tange a diferenciação entre sítios e fazendas, importante exemplo tem-se ao analisar o contexto de ocupação do espaço geográfico desde os primeiros momentos da colonização no Piauí, mais especificamente no século XVIII, onde e quando o sítio era uma estrutura voltada, às vezes, à criação de caprinos/ovinos, mas frequentemente utilizada para o cultivo; já a fazenda, era retratada como uma vasta extensão de terra em cujo espaço predominava a prática da pecuária (MOTT, 1985).
} 
No entanto, a casa do sítio Culumins (Figura 3) chama atenção por diferir destes dois modelos de moradia, pois, os elementos da estrutura que ainda se mantém parte da frente onde é possível observar duas janelas e as seções de paredes da cozinha, além do muro que delimita o quintal -, são de alvenaria de junta seca, ou mista, com alvenaria de pedra com rejunte de cal desde o alicerce às paredes e com revestimento (FERREIRA et al., 2017). Existem, contudo, alguns pontos em que reparos na edificação implicaram na inserção de material cerâmico construtivo (tijolos ou telhas), fragmentados ou inteiros.

Construções em cuja alvenaria foram utilizadas rochas e que se encontram em zonas no sertão nordestino podem ser associadas a diferentes períodos entre os séculos XVII e XX (FERREIRA et al., 2017). Na arquitetura do Seridó, poucas foram as edificações associadas aos séculos XVII-XIX que utilizaram na alvenaria pedra e cal e que ficaram registradas, sendo a Casa Forte do Cuó, utilizada como centro de defesa no período dos conflitos da Guerra dos Bárbaros no final do século XVII, e a Casa de Pedra, como é conhecida uma estrutura de moradia localizada na região central da cidade de Caicó, que até hoje é utilizada como residência e à qual a memória local atribui a data de sua construção como sendo o início do século XVIII. 

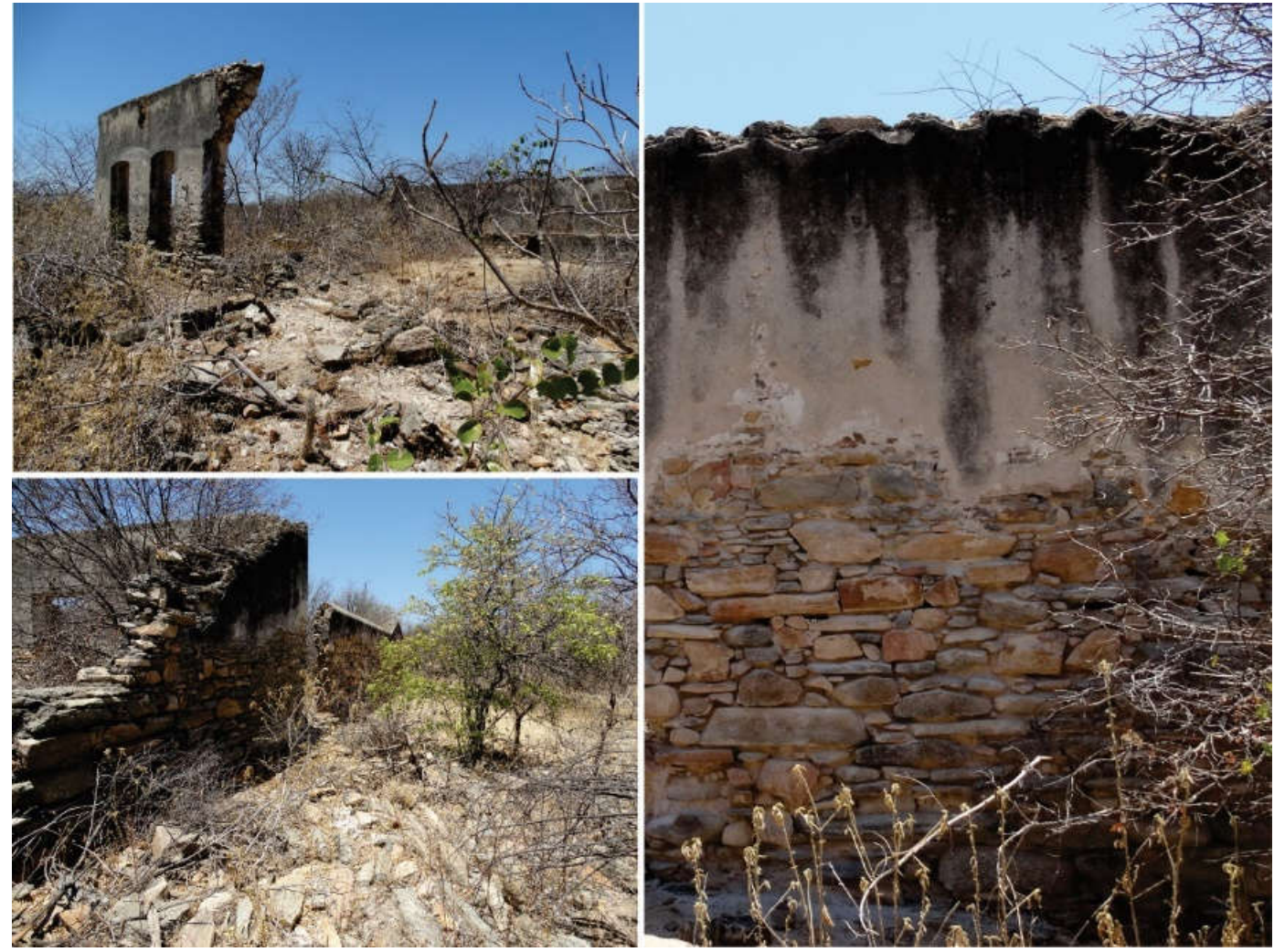

Figura 3. Composição de imagens, onde no alto à esquerda têm-se a parte frontal, com duas janelas ainda aparentes; embaixo à esquerda são parte da parede de um dos quartos e o muro do quintal; no lado direito, vê-se detalhe da parede da cozinha com elementos de uma "arquitetura de pedra seca", com pedras maiores dando estabilidade e pedras menores fazendo o preenchimento de vãos, porém, neste caso, apresentando argamassa de areia e cal. Fotografia e montagem: Abrahão Sanderson.

Por conseguinte, esse estilo de construção consiste como exceção na forma de moradia no sertão do Rio Grande (MACÊDO, 2007: 151). Diante disso, essas edificações remetem ao modelo construtivo das casas fortes, caracterizado pelo 
emprego da alvenaria de pedras e o uso da cal na edificação contendo paredes espessas, comum para o período colonial. Elas atuaram também como estratégia de ocupação e colonização do espaço que era de cunho civil, mas com defesa militar que visava, sobretudo, a garantia de proteção e segurança (SILVA, 2005).

No início do século XX, a construção de um açude na área do sítio Manhoso implicou, devido a prioridade atribuída ao acesso a água, em uma saída do grupo doméstico da casa do Culumins, passando, então, esta casa a ficar desabitada. Ademais, parte da estrutura foi demolida e teve seus materiais construtivos aproveitados na edificação da moradia no sítio Manhoso ${ }^{8}$. Assim, o abandono da casa e a transformação de sua alvenaria e cobertura em matéria-prima para outra(s) residência(s), implicou no arruinamento da casa do Culumins e foi esse o quadro com o qual a equipe de arqueologia se deparou por ocasião de sua primeira ida ao sítio arqueológico, antes da realização das intervenções neste lugar.

A identificação do sítio Culumins enquanto espaço de pesquisa arqueológica ocorreu a partir de contatos com a população local, ainda no ano de 2016. Posteriormente, as atividades de pesquisa também aconteceram no sentido de identificar possível documentação escrita, o que ocorre de forma espaçada e praticamente não foram encontrados documentos, como assentos de batismo ou inventários, por exemplo, que fornecessem outros dados sobre os grupos

\footnotetext{
${ }^{8}$ Informações obtidas através de conversa informal com Fernando Costa, membro da família que atualmente detêm a propriedade do sítio Culumins.
} 
domésticos que ocuparam este espaço. Assim, a produção de informações está mais relacionada à pesquisa oral, ainda em andamento, e aos dados arqueológicos oportunizados a partir de intervenções arqueológicas e as análises de laboratório, que também seguem em execução, conforme projeto de pesquisa de mestrado anteriormente referido.

A primeira escavação ocorrida na área do sítio arqueológico, a partir da qual traçamos nossos apontamentos neste texto, implicou na delimitação de $16 \mathrm{~m}^{2}$, subdividido em 16 unidades de escavação, localizadas na parte do terreno identificada como espaço de acúmulo de lixo doméstico. O nivelamento da superfície, considerando a topografia do lugar, ocorreu a partir da atribuição de um $Z=20 \mathrm{~cm}$, sendo também atribuído o nível arbitrário de 10 centímetros para cada decapagem.

Toda a área de $16 \mathrm{~m}^{2}$ delimitada foi escavada, contudo, a profundidade atingida ocorreu de forma não uniforme, pois, de forma diferenciada houve nas quadrículas o afloramento de ortognaisse ou deixou de haver níveis arqueológicos permanecendo apenas latossolos cinza ou alaranjados. Assim sendo, apenas quatro unidades foram escavadas até o nível 4, enquanto 6 quadrículas foram escavadas até o nível 3 e outras 6 unidades foram escavadas apenas até o nível 2.

Desde a superfície, a área de escavação apresentou fragmentos de cerâmica utilitária, faiança fina, grés, porcelana; fragmentos e recipientes de vidro e ossos 
ligados a arqueofauna (Figura 4). Houve ainda a evidenciação de materiais cerâmicos construtivos e seis moedas, com período de circulação associado ao século XIX, sendo que duas dessas apresentam furos na orla, podendo incidir sobre práticas culturais específicas a depender de análises ainda em curso.

O material arqueológico durante as decapagens apareceu disperso em sua maior quantidade, inclusive, motivado por fatores pós-deposicionais, como a existência de raízes. Houve, contudo, a concentração em dois locais no setor nordeste, onde também foram identificados carvão, estrutura de fogueira e evidências arqueofaunísticas, como costelas e vértebras de bovinos, embora, a arqueofauna no sítio não esteja apenas associada a animais domésticos, tendo ocorrido ossos associados à caça de pequeno porte, de animais como o Euphractus sexcinctus (Tatu peba).

Ao longo de 11 (onze) dias de atividades de campo foram coletadas 6.467 peças, representadas pelos seguintes percentuais: $68 \%$ sendo fragmentos de cerâmica utilitária; 17\% material arqueofaunístico (ossos, fragmentos de ossos e malacológicos); $10 \%$ são genericamente chamados de "louça", apenas para diferenciação da cerâmica utilitária que, também, é um tipo de louça, mas esse grupo é formado por fragmentos de faiança fina, grés e porcelana; $4 \%$ corresponde a recipientes de vidro ou fragmentos destes; além do que, o $1 \%$ restante, é formado por peças metálicas, madeira, cerâmico construtivo e lítico. 


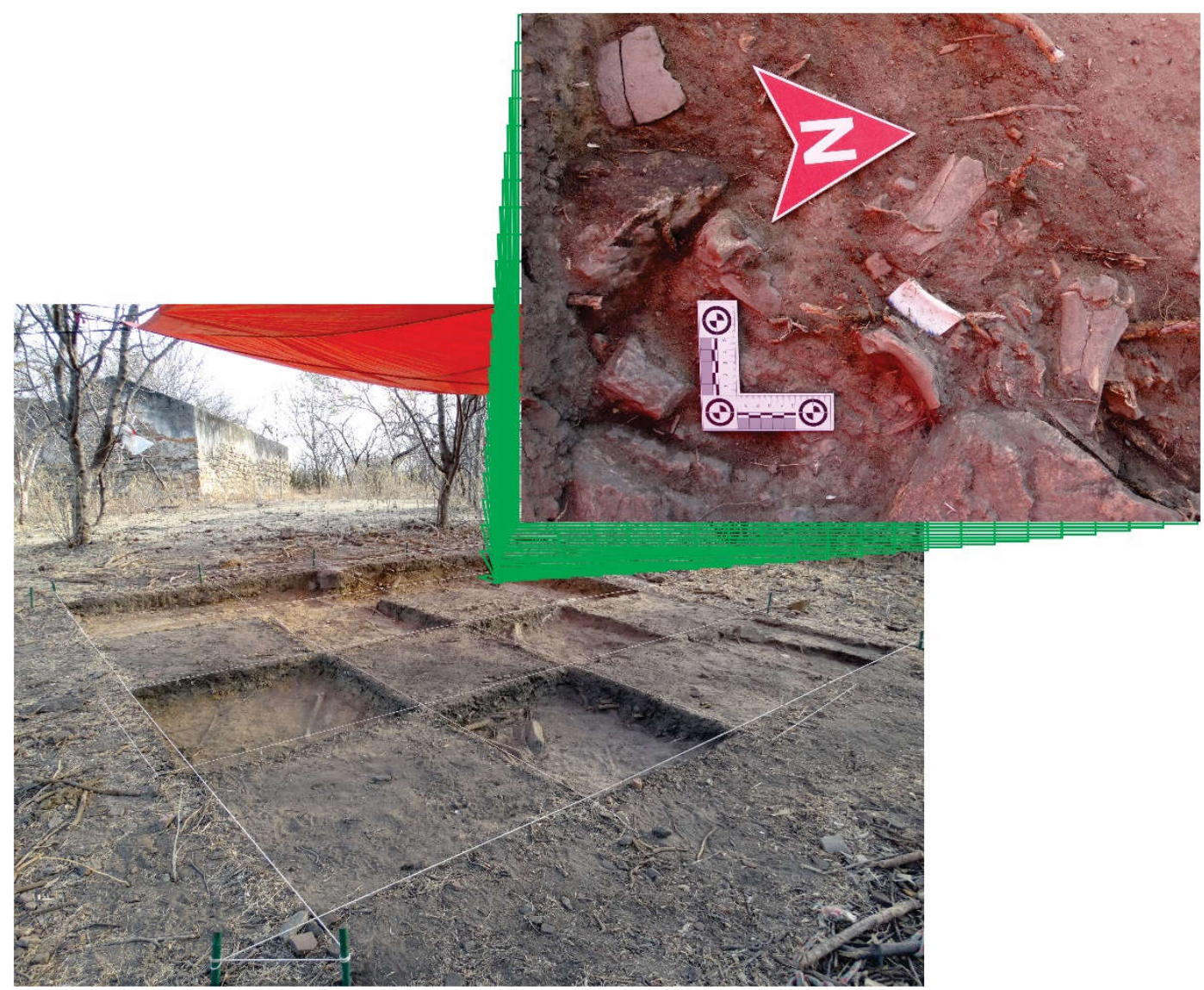

Figura 4. Montagem de fotos evidenciando a área de escavação, com as quadrículas em diferentes estágios e detalhe da quadrícula D4, durante a evidenciação de materiais arqueológicos na decapagem do nível 3. Fotografia e montagem: Abrahão Sanderson. 
Para além do material arqueofaunístico, metais e outras evidências, os quais ainda estão em estudo, os dois principais conjuntos de peças coletadas no sítio Culumins foram fragmentos de cerâmica utilitária e de "louças" (Figura 05), havendo em larga escala a sobreposição do primeiro conjunto, inclusive, de forma semelhante ao que ocorre nos outros casos ligados ao estudo de grupos domésticos sertanejos abordados neste texto (SYMANSKI, 2008; SOUZA, 2015; SOUZA, 2017; HERBERTS, 2019).

Apesar da semelhança em relação às princípais categorias de vestígios arqueológicos coletados, o Culumins, não se encaixa no padrão arquitetônico ou mesmo no pretenso padrão aquisitivo dos grupos abordados nesses trabalhos, isto, em face dos dados sobre a posse da terra encontrados e sobre a casa sede que ainda hoje subsiste nesse espaço e que se diferencia das "tradicionais casas de barro comumente construídas na região, feitas de matéria-prima abundante e gratuita, dotadas da característica única de poderem ser carregadas por seus proprietários" (SOUZA, 2017: 76), ainda assim, são sertanejos sob os quais nada foi escrito e sob os quais importa-nos saber. 

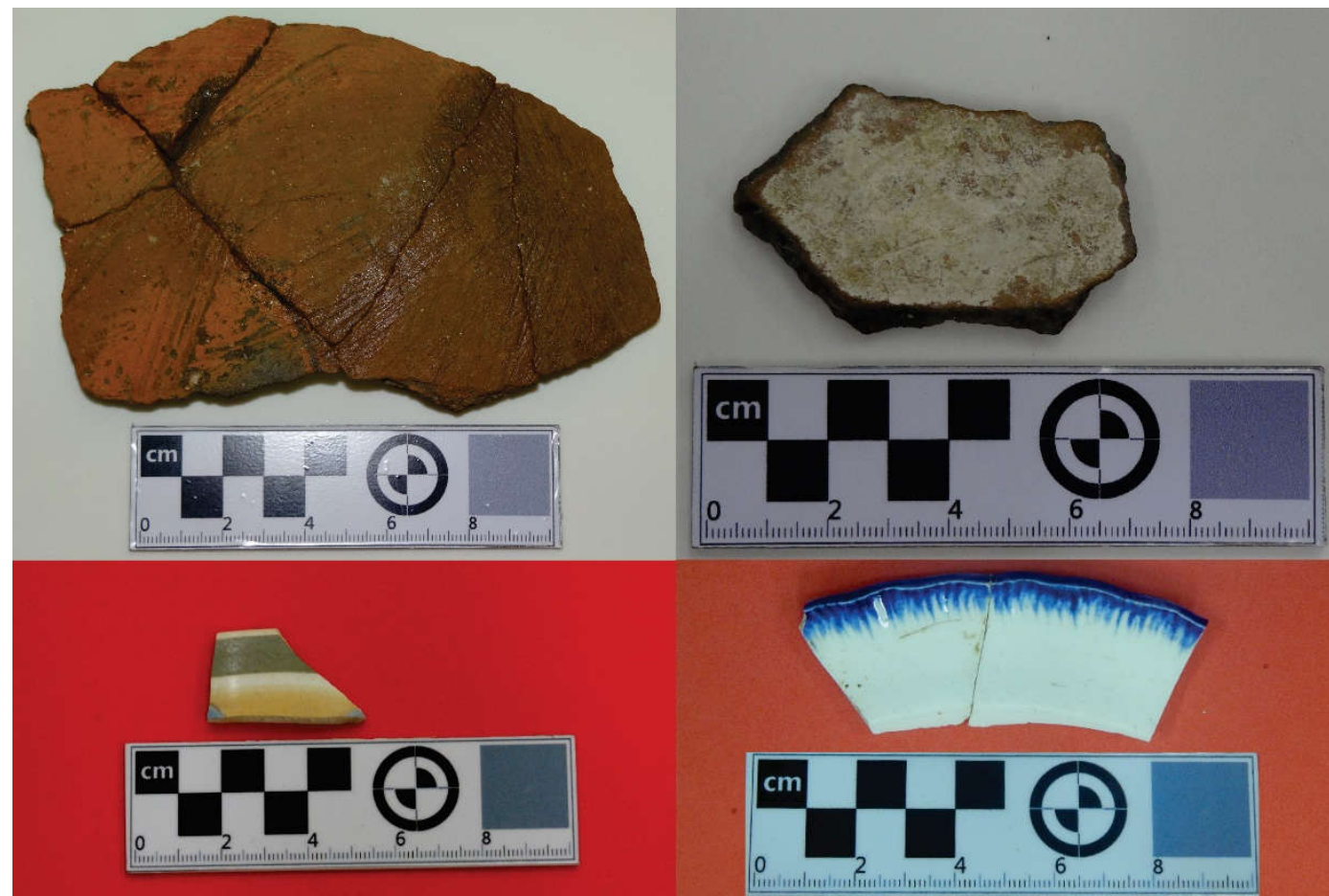

Figura 5. Composição de fotos, com peças coletadas durante a escavação no sítio Culumins. No alto duas imagens de cerâmicas, do lado direita um fragmento com engobo branco e à a esquerda peça remontada apresentando tratamento escovado, embaixo, faianças finas com motivos decorativos, faixas e Shell Edged. Fotografia e montagem: Abrahão Sanderson.

Neste sentido, Vieira Júnior (2004) traz importante reflexão, ao dizer que "a diferenciação entre a casa do fazendeiro e as casas de seus empregados e agregados não era ancorada nas distinções arquitetônicas, mas sim na posse da terra, do rebanho e dos escravos" (VIEIRA JR., 2004: 77). Assim sendo, seria muito possível 
que as sociabilidades nesses ambientes fossem marcadas pela distinção e dependência.

As chamadas "louças" apresentaram três tipos de pasta: faiança fina, grés e porcelana; enquanto as classes de fragmentos que compõem o conjunto são formadas por fragmentos de parede, maior parte da amostra, bordas, apêndices e bases. As superfícies dos fragmentos apresentam características de rugoso, vidrado transparente na maioria da amostra e, polido, sendo que nessas superfícies aparecem decorações: banhadas (dipped), pintadas à mão, relevos, esponjado e carimbos.

Um percentual pequeno da amostra, 13,7\%, apresenta motivos decorativos, inclusive na borda. Os motivos identificados foram: Faixa ou friso, Peasant Style; Spring Style; Floral; Geométrico; Folhas; Faixa simples e Shell Edged, presente em $80 \%$ das peças que possuem motivos decorativos. As classes dos fragmentos de louça, a exceção dos apêndices - que estão associados a alças do tipo "asa" de xícaras -, reporta tratar-se de fragmentos de pratos, em sua maioria, ou de outros recipientes como malgas ou tigelas.

Por outro lado, a análise da cerâmica utilitária histórica foi organizada a partir de atributos como modo de produção, acabamento das superfícies externa e interna, tipo de lábio, borda, corpo, base, apêndice, marcas de uso, tipo de núcleo e antiplástico. Dentro dessas características, naquilo que cumpre ao modo de produção, 0,4\% das peças mostraram evidência do uso do torno na confecção, 
enquanto que $57 \%$ da amostra evidenciou o roletado como principal forma de confecção, seguido pelo modelado que aparece em $42 \%$ das peças analisadas, sendo o percentual de $2,4 \%$ correspondente aos fragmentos sem leitura, ou, cuja maneira de confecção não foi identificada.

O antiplástico presente na cerâmica utilitária coletada no Culumins pode ser agrupado nos seguintes conjuntos: mineral (presente em $90 \%$ dos fragmentos); caco moído; mineral e caco moído; e, mineral e carvão. As superfícies dos fragmentos possuem como tratamentos: alisado, predominante em $75 \%$ das peças; inciso; escovado; polido; pintado e engobo branco. Já a queima nos fragmentos analisados é dividida em: parte central escura (14,9\%); variação de cinza a preto $(61,9 \%)$; variação de branco a vermelho tijolo $(17,4)$; camada clara próxima a superfície interna $(2,5 \%)$ e, camada clara próxima a superfície externa $(3,3 \%)$.

O conjunto de cerâmicas utilitárias representa a maior quantidade do material coletado durante a escavação. Esta amostra é composta genericamente pelo que foi denominado de cerâmicas de produção local e regional, embora alguns dos fragmentos presentes no conjunto de peças cerâmicas utilitárias históricas do sítio Culumins, apresentem características não abordadas em textos que qualificaram esse tipo de cerâmica, como a presença do engobo, por exemplo, no Nordeste do Brasil (SYMANSKI, 2008; AMARAL, 2012; REGO, 2013; QUEIROZ, 2015; SOUZA, 2017; AMARAL, 2019). 
Ao mesmo tempo, as cerâmicas também evidenciam elementos de subsistência ligada às localidades, com as cerâmicas sendo produzidas também na área do sítio ou da fazenda, ou mesmo das pequenas propriedades, tal qual pode ser observado em outros sítios ligados às populações sertanejas, ou mesmo com vinculação à circulação de mercadorias através de mecanismos já observados na literatura arqueológica (SYMANSKI, 2008; SOUZA, 2015), como as feiras livres.

\section{À GUISA DE CONCLUSÃO: ARTICULANDO SERTÃO DO SERIDÓ, CULTURA MATERIAL NO CULUMINS E DINÂMICA SOCIAL}

O caráter dos objetos no âmbito da sociedade sertaneja dos séculos XVIII e XIX e também os aspectos inerentes às vivências em casas de fazenda para ser melhor compreendidos, demandam leituras da materialidade não somente como mercadorias, mas buscando seus significados sociais em meio às estruturas sociais/comerciais a que estes estão inseridos.

As casas de fazenda não podem ser pensadas dentro de modelos lineares ou reducionistas, haviam os ricos proprietários e os menos afortunados; assim como haviam os proprietários pequenos ou grandes que são afetados pela seca, perdendo poder aquisitivo e naquilo que cumpre os objetos, vinculando-se mais aos bens passiveis de serem produzidos com matérias primas disponíveis em seus solos e tendo seus usos articulados às necessidades diárias de seus cotidianos. Não obstante 
isso, convém observar as fazendas e o registro arqueológico proveniente desses lugares, como produto de espaços de moradia de donos, trabalhadores, agregados, escravos e demais parentes do proprietário (VIEIRA JR., 2004).

Ademais, entre todos os vestígios os mais encontrados, estão na categoria de tralha doméstica, como talheres, peças de louças, peças de cerâmica, artefatos de costura, e evidências ósseas relacionadas à pecuária ou a caça. Estes materiais, nos remonta a um espaço especial, as cozinhas (MOURA \& ALLEN, 2015). Para além desse contexto, podemos entender as peças cerâmicas como um dos principais componentes da autonomia sertaneja seridoense no século XIX, se desprendendo da dependência do litoral ou do governo imperial.

A ligação das peças cerâmicas é demasiadamente muito mais presente com as populações sertanejas, sobretudo, pelos laços familiares que são refletidos nos aspectos de sua produção. Estas cerâmicas, trazem consigo a presença das tradições que são perpassadas de geração para geração.

A cerâmica de produção local/regional faz parte do sistema interno de abastecimento que perdura no semiárido até os dias atuais, produzidas por mulheres oleiras, as loiceiras, em pequenos fornos domésticos, fruto de um saber fazer é passado por gerações (Amaral, 2012), mas que se reinventa frente às mudanças nas práticas de consumo. (AMARAL, 2012. apud. SOUZA, 2015: 48). 
Para o sertão do Seridó, dentro da dinâmica social/comercial que se estabelece entre os séculos XVIII e XIX, entendemos as casas de fazenda como polos de produção comercial e manufatureira, mas também entendemos que essas assumem grande papel dentro da interação social/cultural dos grupos.

Nesse sentido, entendemos o Sertão do Seridó enquanto "Chão + Identidade", seguindo a perspectiva de Milton Santos, no que diz respeito a um território usado.

O território é o fundamento do trabalho; o lugar de residência, das trocas materiais e espirituais e do exercício da vida. O território em si não é uma categoria de análise em disciplinas históricas, como geografia. É o território usado que é uma categoria de análise. (SANTOS, 2007: 14).

Nesse território usado, as populações desenvolviam suas vivências, construíam seus lares e moldavam o mundo a sua volta. Nesses espaços as características culturais/sociais dos indivíduos relacionaram-se e construíram com o tempo, as tradições, os gostos, os ritos, os princípios familiares que até hoje estão presentes em maior ou menor grau, no imaginário sertanejo do Seridó.

Dentro dos mecanismos sociais desse território usado, outros espaços podem ser lembrados, como as feiras livres. Locais onde os objetos eram vendidos e comprados, esses espaços representam a interação da convivência entre os grupos. Eram também responsáveis pelo o escoamento da produção local dos vasos, tigelas 
e panelas cerâmicas que eram produzidas nas fazendas. Como também, pela chegada de outros objetos que vinha da maioria das vezes das áreas litorâneas como peças as louças (faianças) portuguesas e inglesas, por exemplo.

Ambos os espaços (casas de fazendas e feiras livres) são engrenagens das vivências e nesse sentido, a cultura material nos permite acessar problemas que estão ligados ao território (sertão) e/aos sertanejos. A final de contas as "Coisas, veja bem, não coisas individuais, mas todo o sistema de coisas, com sua ordem interna, faz de nós as pessoas que somos". (MILLER, 2013: 83).

Dar voz aos sertanejos do Culumins, que nasceram, cresceram e morreram sem nem ao menos deixar algo escrito é, a partir da arqueologia, contar histórias sobre esses grupos e suas relações sociais e culturais, talvez, não no sentido "do que eles foram", mas do que podemos compreender a partir deles.

\section{REFERÊNCIAS:}

ADICHIE, Chimamanda Ngozi. 2009. O perigo de uma História Única. São Paulo: Companhia das Letras.

ALLISON, Penelope M.. The Household in Historical Archaeology. Australasian Historical Archaeology. n. 16, 1998.

AMADO, Janaína. 1995. "Região, sertão, nação". Revista Estudos Históricos, v. 8 (15). Rio de Janeiro: CPDOC/FGV; Ed. FGV, 145-152. 
AMARAL, Daniella Magri. 2012. Loiça de barro do Agreste: um estudo etnoarqueológico de cerâmica histórica pernambucana. Dissertação de Mestrado, Programa de PósGraduação em Arqueologia, Museu de Arqueologia e Etnologia da Universidade de São Paulo, São Paulo.

AMARAL, Daniella Magri. 2019. Loiceiras, potes e sertões: um estudo etnoarqueológico de comunidades ceramistas no agreste central pernambucano. Tese de Doutorado, Programa de Pós-Graduação em Arqueologia, Museu de Arqueologia e Etnologia da Universidade de São Paulo, São Paulo.

ARAUJO, Soraya Geronazzo. 2007. O Muro do Demônio: economia e cultura na Guerra dos Bárbaros no nordeste colonial do Brasil - séculos XVII e XVIII. 2007. 122 f. Dissertação de Mestrado, Programa de Pós-graduação em História, Universidade Federal do Ceará, Fortaleza/CE.

BARTELT, Dawid Danilo. 1999. "O custo da Modernização: Dissociação, Homogeneização e Resistência no Sertão do Nordeste Brasileiro". Revista Canudos. Salvador/BA. n. 1, v. 3.

BONATO, Tiago. 2010. O olhar, a descrição: a construção do sertão do Nordeste brasileiro nos relatos de viagem do final do período colonial (1782-1822). Dissertação de Mestrado, Universidade Federal do Paraná, Programa de Pós-graduação em História.

BORGES, Ariane Magda. 2015. Vernaculares: a casa de fazenda seridoense do século XIX como exemplo de adaptação ao clima semiárido. Dissertação de Mestrado, Programa de Pós-Graduação em Arquitetura, Universidade Federal do Rio Grande do Norte, Natal.

BRAUDEL, Fernand. 2014. Escritos sobre a História. São Paulo: Perspectiva.

BRUNO, Maria Cristina Oliveira. 1995. Musealização da Arqueologia: um estudo de modelos para o Projeto Paranapanema. Tese de Doutorado, Universidade de São Paulo/USP, Programa de Pós-Graduação Interdepartamental em Arqueologia.

CARRÉRA, Mércia; SURYA, Leandro. 2008. A organização espacial de uma fazenda colonial beditina: reflexo da estruturação social vigente. Mneme - Revista de Humanidades. v. 9, (24). 
DINIZ, Nathália Maria Montenegro. 2008. Velhas fazendas da Ribeira do Seridó Dissertação de Mestrado, Programa de Pós-Graduação em Arquitetura, Universidade de São Paulo.

DINIZ, Nathália Maria Montenegro. 2013. Um Sertão entre tantos outros: fazendas de gado nas ribeiras do Norte. Tese de Doutorado, Programa de Pós-Graduação em Arquitetura, Universidade de São Paulo, São Paulo.

FEIJÓ, Paulo Heider Forte. 2002. A arquitetura tradicional de Acari no século XIX: estudo comparativo entre a casa grande de fazenda e a casa urbana. Dissertação de Mestrado, Programa de Pós-graduação em Arquitetura da Universidade Federal do Rio Grande do Norte, Natal.

FERREIRA, Jônatas Alves; FREITAS, Mariana; MATOS, Manoela Xavier Gomes de; SOUTO MAIOR, Paulo Martin. 2017. "Além da pedra: utilização de rochas em alvenarias nas zonas rurais no Nordeste do Brasil, séculos XVIII ao XX”. FUMDHAMENTOS, v. 17. São Raimundo Nonato/PI.

HERBERTS, Ana Lucia. 2019. “Arqueologia das populações sertanejas no Nordeste brasileiro". In: Anais do XX Congresso da Sociedade de Arqueologia Brasileira: Memória, Patrimônio Cultural e Direitos Humanos. Pelotas/RS.

LEAL, Victor Nunes. 2012. "Indicações sobre a estrutura e o processo do "coronelismo"”. In: LEAL, Victor Nunes. Coronelismo, enxada e voto: o município e o regime representativo no Brasil. O município e o regime representativo no Brasil. São Paulo: Companhia das Letras, 43-51.

LIMA, Tânia Andrade. 1993. “Arqueologia histórica no Brasil: balanço bibliográfico (1960-1991)”. Anais do Museu Paulista. São Paulo. v. 1 (1).

MACÊDO, Muirakytan Kennedy de. 2007. Rústicos Cabedais: patrimônio e cotidiano familiar nos sertões do Seridó (séc. XVIII). Tese de Doutorado, Programa de Pósgraduação em Ciências Sociais, Universidade Federal do Rio Grande do Norte, Natal.

MACÊDO, Muirakytan K. de. 2012. A penúltima versão do Seridó: Uma história do regionalismo seridoense. Natal-RN/Campina Grande/PB: Editora da Universidade Estadual da Paraíba. 
MARTIN, Gabriela. 2013. Pré-História do Nordeste do Brasil. Recife: EDUFPE.

MEDEIROS FILHO, Olavo de. 1983. Velhas Inventários do Seridó. Brasília: Centro Gráfico do Senado Federal.

MILLER, Daniel. 2013. Trecos, Troços e Coisas: estudos antropológicos sobre a cultura material. Rio de Janeiro: Zahar.

MONTEIRO, John Manuel. 2001. Tupis, Tapuias e Historiadores: estudos de História Indígena e do Indigenismo. Tese de Livre Docência. Universidade Estadual de Campinas.

MONTEIRO, Denise. 2002. Introdução à história do Rio Grande do Norte. Natal: EDUFRN.

MORAES, Antonio Carlos Robert. 2003. "O Sertão. Um outro geográfico”. In: Terra Brasilis [Online]. n. 4 - 5. Disponível em: http://journals.openedition.org/terrabrasilis /341- Acessado em 11/06/2020.

MOTT, Luiz R. B. 1985. Piauí colonial. População, economia e sociedade. Teresina: Projeto Petrônio Portella.

MOURA, Herbert; ALLEN, Scott J. 2015. "O Gosto do Barro: Memória culinária e Morfológica das Cerâmicas utilitárias de Pernambuco". Vestígios - Revista Latinoamericana de Arqueologia Histórica, Belo Horizonte, v. 9 (2), 10-32.

NEVES, Erivaldo Fagundes. 2003. "Sertão como recorte espacial e como imaginário cultural”. Politeia: Hist. e Soc, Vitoria da Conquista. v. 3, (1), 153-162.

POLLAK, Michel. 1992. Memória e identidade social. Estudos Históricos. Rio de Janeiro. v. $5,(10)$.

QUEIROZ, Luiz Antonio Pacheco de. 2015. Água fria é no pote do Cariri Cearense. Dissertação de Mestrado, Universidade Federal de Sergipe, Programa de Pós-Graduação em Arqueologia. 
REGO, Herbert Moura. 2013. As panelas de barro de Pernambuco - do século XIX ao XXI. Dissertação de Mestrado, Programa de Pós-Graduação em Arqueologia, Universidade Federal de Pernambuco, Recife.

SÁ, Antônio Fernando de Araújo. 1997. "Canudos Plural: Memórias em confronto nas comemorações dos centenários de Canudos (1993-1997)". Textos de História (UnB), Brasília/DF, v. 5 (1).

SANTOS, Milton. 2007. "O Dinheiro e o Território”. In: SANTOS, Milton; BECKER, Bertha K. (org.). Território, Territórios: ensaios sobre o ordenamento territorial. Ensaios sobre o ordenamento Territorial. Rio de Janeiro: Lamparina. 13-21.

SILVA, Roberto Airon. 2005. "Arqueologia Colonial: as Casas Fortes (de Pedra) como unidades de defesa e ocupação no Rio Grande do Norte no Século XVII". Mneme-Revista de Humanidades, v. 6 (13), 111-122.

SILVA, Roberto Airon. 2010. Uma arqueologia das casas fortes: organização military, território e guerra na Capitania do Rio Grande - Século XVII. Tese de Doutorado, Universidade Federal da Bahia, Programa de Pós-Graduação em Ciências Sociais.

SILVA, Fabíola Amaral Jansen da. 2006. O cativeiro rural colonial: reconstituição arqueológica da senzala da fazenda São Bento de Jagauaribe, município de Abreu e Lima - Pernambuco. Dissertação de Mestrado, Universidade Federal de Pernambuco, Programa de Pós-Graduação em Arqueologia.

SOUZA, Rafael de Abreu e. 2015. "Globalização, Consumo e Diacronia: populações sertanejas sob a ótica Arqueológica". Revista Latino-americana de Arqueologia Histórica, Belo Horizonte, v. 9 (2), 38-62.

SOUZA, Rafael de Abreu e. 2017. Um Lugar na Caatinga: consumo, mobilidade e paisagem no semiárido do Nordeste Brasileiro. Tese de Doutorado, Universidade Estadual de Campinas. Campinas.

SYMANSKI, Luís Cláudio P. 2008. "Práticas econômicas e sociais no sertão cearense no século XIX: um olhar sobre a cultura material de grupos domésticos sertanejos". Revista de Arqueologia, v. 21 (2). 
SYMANSKI, Luís Cláudio P. 2009. “Arqueologia histórica no Brasil: uma revisão dos últimos vinte anos". In: MORALES, Walter Fagundes (Org.); MOI, Flávia Prado (Org.). Cenários regionais em arqueologia brasileira. São Paulo: Annablume; Porto Seguro/BA: ACERVO - Centro de Referência em Patrimônio e Pesquisa.

VIEIRA JR., Antonio Otaviano. 2004. Entre paredes e bacamartes: história da família no sertão (1780-1850). Fortaleza: Edições Demócrito Rocha; Hucitec.

ZANETTINI, Paulo Eduardo. 2003. “Arqueologia na caatinga: arqueologia de Canudos, em Canudos ou para Canudos?”. In: Comciência. Dossiê: Arqueologia. n 47. Disponível em: http://www.comciencia.br/ - Acessado em 09/06/2020.

ZANETTINI, Paulo Eduardo. 1996. "Por uma arqueologia de Canudos e dos brasileiros iletrados". Revista Canudos. Salvador/BA. n. 1, v. 1. 